\title{
Nitrogen mineralization in an Alfisol amended with thermoelectrical industry by-products
}

\author{
Claudio Fernāndez ${ }^{1}$, Neal Stolpe ${ }^{1}$, José E. Celis ${ }^{2}$, and Marco A. Sandoval ${ }^{1^{*}}$
}

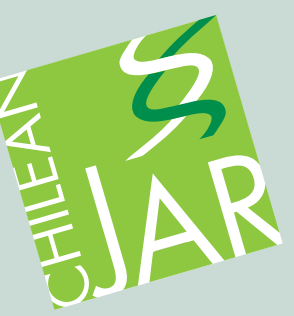

\section{ABSTRACT}

In thermoelectric industry, synthetic gypsum and coal ash are generated as industrial by-products. The objective of this work was to evaluate the effect of different mixtures of synthetic gypsum and coal ash on $\mathrm{N}$ mineralization in an Alfisol. Nitrogen mineralization was evaluated by soil incubations under controlled conditions and potential mineralization using the nonlinear first order kinetics model $N m_{t}=N_{0}\left[1-\mathrm{e}^{(-k \mathrm{t})}\right]$, where $N m_{t}$ is the mineral $\mathrm{N}$ accumulated at a specific time, $N_{0}$ is the potentially mineralizable $\mathrm{N}, k$ is the mineralization rate, and finally $t$ is the incubation time. Treatments consisted of different mixtures of synthetic gypsum, coal ash and urea $\left(\mathbf{M}_{1}\right.$ : $50 \%$ synthetic gypsum, $50 \%$ coal ash, $\mathrm{M}_{2}: 50 \%$ synthetic gypsum, $35 \%$ coal ash, $15 \%$ urea, $\mathrm{M}_{3}: 45 \%$ synthetic gypsum; $40 \%$ coal ash, $15 \%$ urea, $\mathrm{M}_{4}: 65 \%$ synthetic gypsum, $20 \%$ coal ash, $15 \%$ urea, $\mathbf{M}_{5}: 55 \%$ synthetic gypsum, $30 \%$ coal ash, 15\% urea). Each mixture was applied to the soil at $2 \mathrm{t} \mathrm{ha}^{-1}$. The results shown the highest concentration $(\mathrm{p}<0.05)$ of net mineral $\mathrm{N}\left(\mathrm{N}_{\mathrm{MN}}\right)$ applying $\mathrm{M}_{3}\left(166.14 \mathrm{mg} \mathrm{kg}^{-1}\right)$, while the lowest $\mathrm{N}_{\mathrm{MN}}(\mathrm{p}<0.05)$ was found applying $\mathrm{M}_{5}\left(98.30 \mathrm{mg} \mathrm{kg}^{-1}\right)$. Treatment $\mathrm{M}_{1}$ presented the highest $\mathrm{N}_{0}$ value $\left(579.0 \mathrm{mg} \mathrm{kg}^{-1}\right)$ respect to treatments with urea in its composition, with exception of $\mathrm{M}_{3}$ (523.4 $\left.\mathrm{mg} \mathrm{kg}^{-1}\right)$. Where the highest and lowest $\mathrm{k}$ were determined in $\mathrm{M}_{5}(\mathrm{k}=0.44990)$ and $\mathrm{M}_{3}(\mathrm{k}=0.04470)$, respectively. Mixtures of synthetic gypsum, coal ash and urea increased $\mathrm{N}$ mineralization over mixtures without urea. Respect $\mathrm{N}$ potential mineralization, in some cases $\mathrm{N}_{0}$ and $\mathrm{k}$ values would respond more to the fit of the mathematical model employed than to the biological process.

Key words: Coal ash, FGD gypsum, N mineralization, soil amendment.

${ }^{1}$ Universidad de Concepción, Facultad de Agronomía, Av. Vicente Méndez 595, Chillán, Chile.

"Corresponding author (masandov@udec.cl).

${ }^{2}$ Universidad de Concepción, Facultad de Ciencias Veterinarias, Av. Vicente Méndez 595, Chillán, Chile.

Received: 3 March 2017.

Accepted: 24 August 2017.

doi:10.4067/S0718-58392017000400400

\section{INTRODUCTION}

In Chile, 10.4 million tons of solid industrial waste were generated in year 2009, which has generated a total of 4961 tons of non-hazardous industrial waste. Some wastes are considered by-products like synthetic gypsum and coal ash from thermoelectric industries, which use coal as fuel to generate energy.

In the thermoelectric industry, because of the process of desulfurization of gases produced during coal combustion, synthetic gypsum is generated (FGD gypsum; Flue Gas Desulfurization) as a by-product. For this, combustion gases are first exposed to a slurry of hydrated lime forming calcium sulfite $\left(\mathrm{CaSO}_{3} \times 5 \mathrm{H}_{2} \mathrm{O}\right)$, by capture of $\mathrm{SO}_{2}$, it is oxidized to form synthetic gypsum (calcium sulfate), and finally the excess water is removed (Chen and Dick, 2011).

Conventionally, both FGD gypsum and ash are deposited in landfills. However, for some years it has been sought to recycle nutrients present in these residues, applying them as conditioners of agricultural, forest, and degraded soils (Tyagi and Lo, 2013; Niu et al., 2016).

FGD gypsum represents an alternative of substitution for mineral gypsum applied to agricultural soils (DeSutter and Cihacek, 2009), which is widely used in agriculture as soil amendment. When applied to soil, Ca present in mineral gypsum causes a cation exchange complex, releasing the $\mathrm{Na}$ molecules, which are replaced by the $\mathrm{Ca}$ of clay layers and thus leaving $\mathrm{Na}$ free for subsequent lixiviation.

Regarding the ash generated by the burning of coal, these are divided into bottom and fly ash. Bottom ash are thicker and heavier, fly ash are produced in industrial combustion and gasification at temperatures between 800 and $1600{ }^{\circ} \mathrm{C}$ (Vassilev et al., 2013). Fly ash remains suspended in combustion gases and corresponds to the finer fraction, which reaches $40 \%$ of total ash produced and are usually removed through electrostatic precipitators and filters (Melotti et al., 2013).

The use of coal ash in agriculture has received great attention during the last four decades (Shaheen et al., 2014). This subproduct has been used as a source of essential nutrients for plants (Ram et al., 2011). Likewise, coal ash has been shown to generate a positive result in soils of acid and neutral $\mathrm{pH}$ in terms of increasing adsorption and retention capacity of $\mathrm{P}$ in the soil; however, in alkaline soils a lower response is observed (Seshadri et al., 2013). There are also reports on the correction of P, Mg, $\mathrm{S}, \mathrm{Mn}, \mathrm{B}, \mathrm{Mo}$, and $\mathrm{Zn}$ deficiencies after the application of coal 
ash, due to the direct contribution of the ash and/or their capacity to increase the availability of these nutrients by $\mathrm{pH}$ corrections (Ram and Masto, 2014).

In soil, by means of mineralization processes, OM releases macronutrients and micronutrients (Rahman et al., 2013). The changes of OM in the soil are governed, in part, by the accessibility of decomposing agents to the organic substrates (Dungait et al., 2012), and by their chemical quality (Jastrow et al., 2007; Conant et al., 2011). This is why the characteristics of MO are commonly studied to infer its potential reactivity (Kögel-Knabner et al., 2008). Sandoval et al. (2010) determined that the addition of organic residues in Entisols and Alfisols reduces their impact on the environment through the decomposition and subsequent mineralization of OM present in them, releasing nutrients that can be used by plants, such as $\mathrm{N}$.

However, the application of FGD gypsum and coal ash does not generate a contribution of $\mathrm{N}$ to soil, which could affect $\mathrm{N}$ mineralization and its availability. Being $\mathrm{N}$ mineralization in soil, an indicator of the amount of organic $\mathrm{N}$ transformed to inorganic at a given moisture content, incubation time and temperature (Gilmour and Mauromoustakos, 2010).

Therefore, the objective of this work was to evaluate the net and potential $\mathrm{N}$ mineralization when applying different mixtures of by-products from the thermoelectric industry in an Alfisol.

\section{MATERIALS AND METHODS}

\section{By-products of the thermoelectric industry and applied} mixtures

The experiment was realized in the Laboratory of Environmental Edafology of the Department of Soils and Natural Resources, Faculty of Agronomy, Universidad de Concepción, Chillán.

Treatments consisted in one control (soil without any addition) and the following mixtures of synthetic gypsum, coal ash and urea: $\mathrm{M}_{1}: 50 \%$ synthetic gypsum, $50 \%$ coal ash, $\mathrm{M}_{2}: 50 \%$ synthetic gypsum, $35 \%$ coal ash, $15 \%$ urea, $\mathrm{M}_{3}: 45 \%$ synthetic gypsum; 40 coal ash, $15 \%$ urea, $\mathrm{M}_{4}$ : $65 \%$ synthetic gypsum, $20 \%$ coal ash, $15 \%$ urea, $\mathrm{M}_{5}: 55 \%$ synthetic gypsum, $30 \%$ coal ash, $15 \%$ urea (Table 1 ).

Synthetic gypsum and coal ash were provided by thermoelectric industry Guacolda located at Huasco $\left(28^{\circ} 28.08^{\prime} 33^{\prime \prime} \mathrm{S}, 71^{\circ} 13^{\prime} 08.18^{\prime \prime} \mathrm{W}\right)$, Chile. Chemical characterization of FGD gypsum and coal ash (Table

Table 1. Amount of synthetic gypsum, coal ash, and urea used to make different mixtures applied to an Alfisol before incubation trials.

\begin{tabular}{lcccc}
\hline Treatment & Nomenclature & $\begin{array}{c}\text { Synthetic } \\
\text { gypsum }\end{array}$ & $\begin{array}{c}\text { Coal } \\
\text { ash }\end{array}$ & Urea \\
\cline { 3 - 5 } Mixture 1 & $\mathrm{M}_{1}$ & 50 & 50 & - \\
Mixture 2 & $\mathrm{M}_{2}$ & 50 & 35 & 15 \\
Mixture 3 & $\mathrm{M}_{3}$ & 45 & 40 & 15 \\
Mixture 4 & $\mathrm{M}_{4}$ & 65 & 20 & 15 \\
Mixture 5 & $\mathrm{M}_{5}$ & 55 & 30 & 15 \\
\hline
\end{tabular}

2) was performed according to the methodology described by Sadzawka et al. (2006). Total N and OM were measured by digestion, while the contents of $\mathrm{P}$, $\mathrm{K}, \mathrm{Mg}$ and $\mathrm{Ca}$ were determined by atomic absorption spectrometry (Perkin-Elmer spectrometer, model 1100B, Phoenix, Arizona, USA).

\section{Soil used for incubation trials}

The soil corresponds to order Alfisol (Fine, halloysitic, mesic, Aquic Palexeralfs) (Stolpe, 2006), samples were collected at a 0-20 cm depth from San Ignacio (36 $46^{\circ}$ '51.01" $\mathrm{S}, 72^{\circ} 00^{\prime} 29.62^{\prime}$ ' W). The management and preparation of the soil samples prior the establishment of the experiment, as well as the determination of the bulk density of the soil were performed based on Sandoval et al. (2012).

The chemical soil characterization (Table 3 ) was performed according to the methodology described by Sadzawka et al. (2006). Water $\mathrm{pH}$ and OM were measured, while concentrations of macronutrients $(\mathrm{P}-\mathrm{Olsen}, \mathrm{K}, \mathrm{Ca}$, $\mathrm{Mg}, \mathrm{Na}$ and $\mathrm{S}$ ) and micronutrients ( $\mathrm{Fe}, \mathrm{Mn}, \mathrm{Zn}, \mathrm{Cu}$ and $\mathrm{B})$ were also determined. The soil has a clay loam texture and a bulk density of $0.85 \mathrm{~g} \mathrm{~cm}^{-3}$.

Table 2. Chemical characterization of synthetic gypsum and coal ash used to make different mixtures applied as treatments.

\begin{tabular}{lcc}
\hline Element & Coal ash & Synthetic gypsum \\
\hline $\mathrm{C}, \%$ & 34.7 & nd \\
$\mathrm{N}, \%$ & 0.57 & $<0.05$ \\
$\mathrm{P}, \%$ & 1.30 & $<0.05$ \\
$\mathrm{~K}, \%$ & 1.26 & nd \\
$\mathrm{Ca}, \%$ & nd & 9.50 \\
$\mathrm{Mg}, \%$ & 1.10 & 0.09 \\
$\mathrm{~S}, \%$ & 0.04 & nd \\
$\mathrm{CaCO}_{3}, \%$ & nd & 0.85 \\
$\mathrm{SO}_{4}^{-2}, \%$ & nd & 52.30 \\
$\mathrm{Si}_{1} \%$ & 5.59 & $\mathrm{nd}$ \\
$\mathrm{Al}, \%$ & 1.14 & $\mathrm{nd}$ \\
$\mathrm{Na}, \%$ & 0.42 & 0.18 \\
$\mathrm{C} / \mathrm{N}$ & 60.9 & nd \\
\hline
\end{tabular}

nd: Not determined.

Table 3. Initial chemical characterization of the Alfisol used in this experiment to determine $\mathbf{N}$ mineralization.

\begin{tabular}{|c|c|}
\hline Parameter & Values \\
\hline $\mathrm{pH}$ & 6.0 \\
\hline $\mathrm{MO}, \%$ & 7.2 \\
\hline CE, dS m ${ }^{-1}$ & 0.08 \\
\hline $\mathrm{N}-\mathrm{NH}_{4}{ }^{+}, \mathrm{mg} \mathrm{kg}^{-1}$ & 12.3 \\
\hline $\mathrm{N}-\mathrm{NO}_{3}^{-}, \mathrm{mg} \mathrm{kg}^{-1}$ & 28.3 \\
\hline $\mathrm{P}, \mathrm{mg} \mathrm{kg}^{-1}$ & 94.3 \\
\hline $\mathrm{K}, \mathrm{cmol}_{\mathrm{c}} \mathrm{kg}^{-1}$ & 2.1 \\
\hline $\mathrm{Ca}, \mathrm{cmol}_{\mathrm{c}} \mathrm{kg}^{-1}$ & 4.4 \\
\hline $\mathrm{Mg}, \mathrm{cmol}_{\mathrm{c}} \mathrm{kg}^{-1}$ & 1.6 \\
\hline $\mathrm{Na}, \mathrm{cmol}_{\mathrm{c}} \mathrm{kg}^{-1}$ & 0.1 \\
\hline $\mathrm{S}, \mathrm{mg} \mathrm{kg}^{-1}$ & 5.1 \\
\hline $\mathrm{Fe}, \mathrm{mg} \mathrm{kg}^{-1}$ & 55.3 \\
\hline $\mathrm{Mn}, \mathrm{mg} \mathrm{kg}^{-1}$ & 37.6 \\
\hline $\mathrm{Zn}, \mathrm{mg} \mathrm{kg}^{-1}$ & 2.5 \\
\hline $\mathrm{Cu}, \mathrm{mg} \mathrm{kg}^{-1}$ & 1.4 \\
\hline $\mathrm{B}, \mathrm{mg} \mathrm{kg}^{-1}$ & 0.9 \\
\hline
\end{tabular}

MO: Organic matter, CE: electrical conductivity. 


\section{Assessment of net $\mathbf{N}$ mineralization}

The effect of the different mixtures was investigated by a completely randomized experimental design with three replicates per treatment. Treatments consisted of a dose equivalent to $2 \mathrm{t} \mathrm{ha}^{-1}$ each mixture $\left(\mathrm{M}_{1}, \mathrm{M}_{2}, \mathrm{M}_{3}, \mathrm{M}_{4}, \mathrm{M}_{5}\right)$, in addition to a control (soil without amendment). Eighteen experimental units consisting of $200 \mathrm{~g}$ of previously sieved soil were prepared in polypropylene bags. Once treatments were applied, experimental units were placed under controlled conditions in an incubator (D-3162, UetzeHänigsen, Germany) maintaining soil moisture at $80 \%$ field capacity and $25^{\circ} \mathrm{C}$. Five evaluation times corresponding to $0,2,4,6$ and 8 wk were used.

The concentrations of $\mathrm{NO}_{3}{ }^{-}$and $\mathrm{NH}_{4}{ }^{+}$were determined by colorimetry with salicylic acid and Nessler reagent, respectively (Keeney and Nelson, 1982) and the entire mineral $\mathrm{N}$ by the sum of both $\mathrm{N}$ forms for each incubation period. Net mineral $\mathrm{N}$ concentration $\left(\mathrm{N}_{\mathrm{MN}}\right)$ was calculated by the difference between total inorganic $\mathrm{N}$ concentrations of each evaluated time minus the total concentration determined at time 0 .

Potential $\mathrm{N}$ mineralization and mineralization rate were determined using the non-linear method of average squares. This regression analysis assumes that $\mathrm{N}$ mineralization is a first-order reaction (Hirzel et al., 2010), using the following model:

$$
N m_{t}=N_{0}\left[1-\mathrm{e}^{(-k \mathrm{t})}\right]
$$

where $N m_{t}$ is the mineral $\mathrm{N}$ accumulated at a specific time $\left(\mathrm{mg} \mathrm{kg}^{-1}\right), N_{0}$ is the potentially mineralizable $\mathrm{N}\left(\mathrm{mg} \mathrm{kg}^{-1}\right)$, $k$ is the mineralization rate and finally $t$ is the incubation time (wk).

\section{Statistical analysis}

The statistical analysis of data obtained in terms of $\mathrm{N}$ mineralization was performed with ANOVA, while the effect of means was analyzed by Tukey's test with a confidence level of $95 \%(\alpha=0.05)$. Potentially mineralizable $\mathrm{N}\left(\mathrm{N}_{0}\right)$ and mineralization rate $(\mathrm{k})$ were determined using the Gauss-Newton method for nonlinear least squares. Data were analyzed using SAS software (SAS Institute, Cary, North Carolina, USA).

\section{RESULTS AND DISCUSSION}

\section{Nitrogen mineralization}

The concentrations of net mineral $\mathrm{N}\left(\mathrm{N}_{\mathrm{MN}}\right)$ determined in the Alfisol had significant differences $(\mathrm{p}<0.05)$ respect to control treatment (Table 4). Throughout the test, $\mathrm{N}_{\mathrm{MN}}$ concentrations in the Control and $\mathrm{M}_{1}$ treatments differed ( $\mathrm{p}<0.05)$ from the $\mathrm{N}_{\mathrm{MN}}$ concentrations presented by treatments $\mathrm{M}_{2}, \mathrm{M}_{3}, \mathrm{M}_{4}$ and $\mathrm{M}_{5}$. Differences were only determined between the Control and $\mathrm{M}_{1}$ treatments $(\mathrm{p}<$ 0.05 ) in the last evaluation. Increasing $N_{M N}$ in soils without addition of organic amendments or $\mathrm{N}$ fertilizer has been reported by Masunga et al. (2016). After 2 wk incubation, treatments $\mathrm{M}_{2}, \mathrm{M}_{3}, \mathrm{M}_{4}$ and $\mathrm{M}_{5}$ showed no differences ( $\mathrm{p}$ $>0.05$ ) respect to $\mathrm{N}_{\mathrm{MN}}$ concentration. During week $4 \mathrm{~N}_{\mathrm{MN}}$
Table 4. Net concentrations of mineral $N\left(N_{M N}\right)$ determined at each incubation time in an Alfisol.

\begin{tabular}{lccrr}
\hline & \multicolumn{4}{c}{ Time (wk) } \\
\cline { 2 - 5 } Treatment & 2 & 4 & 6 & 8 \\
\hline Control & $12.75 \mathrm{~b}$ & $24.46 \mathrm{c}$ & $52.92 \mathrm{c}$ & $48.57 \mathrm{c}$ \\
Mixture 1 & $19.63 \mathrm{~b}$ & $14.19 \mathrm{c}$ & $51.17 \mathrm{c}$ & $74.22 \mathrm{~d}$ \\
Mixture 2 & $74.12 \mathrm{a}$ & $56.61 \mathrm{~b}$ & $120.69 \mathrm{~b}$ & $124.25 \mathrm{~b}$ \\
Mixture 3 & $78.76 \mathrm{a}$ & $65.10 \mathrm{ab}$ & $114.23 \mathrm{~b}$ & $166.14 \mathrm{a}$ \\
Mixture 4 & $76.89 \mathrm{a}$ & $71.67 \mathrm{a}$ & $171.20 \mathrm{a}$ & $131.89 \mathrm{~b}$ \\
Mixture 5 & $71.70 \mathrm{a}$ & $73.87 \mathrm{a}$ & $123.21 \mathrm{~b}$ & $98.30 \mathrm{e}$ \\
\hline CV, \% & 6.41 & 9.98 & 6.65 & 5.04 \\
\hline LSD & 9.77 & 13.95 & 19.28 & 14.83 \\
\hline
\end{tabular}

Mixture 1: 50\% synthetic gypsum; 50\% coal ash. Mixture 2: 50\% synthetic gypsum; 35\% coal ash; $15 \%$ urea. Mixture 3: 45\% synthetic gypsum; $40 \%$ coal ash; $15 \%$ urea. Mixture 4: 65\% synthetic gypsum; $20 \%$ coal ash; $15 \%$ urea. Mixture 5: 55\% synthetic gypsum; 30\% coal ash; $15 \%$ urea.

CV: Coefficient of variation, LSD: least significant difference by Tukey's test. Different letters in a same column means significant differences between treatments $(\mathrm{p}<0.05)$.

concentration generated by treatments $M_{4}$ and $M_{5}$ did not show any significant differences $(\mathrm{p}>0.05)$, but they differed $(\mathrm{p}<0.05)$ from treatment $\mathrm{M}_{2}$. The highest $\mathrm{N}_{\mathrm{MN}}$ increase occurred at week 6 , when treatment $\mathrm{M}_{4}$ generated the highest $\mathrm{N}_{\mathrm{MN}}$ concentration $(\mathrm{p}<0.05)$. Regarding $\mathrm{M}_{2}$, $M_{3}$ and $M_{5}$, these treatments did not present significant differences among them $(\mathrm{p}>0.05)$. However, at week 8 , treatment $\mathrm{M}_{3}$ shown the highest concentration of $\mathrm{N}_{\mathrm{MN}}$ $(\mathrm{p}<0.05)$ with respect to all mixtures with urea in its formulation. Finally, at week 8 there were differences $(\mathrm{p}<$ 0.05 ) in $\mathrm{N}_{\mathrm{MN}}$ concentration between treatments $\mathrm{M}_{4}$ and $\mathrm{M}_{5}$. The behavior of treatments $\mathrm{M}_{2}, \mathrm{M}_{3}, \mathrm{M}_{4}$ and $\mathrm{M}_{5}$ respond to the observations of Nave et al. (2009), who found increments of $\mathrm{N}$ mineralization up to $62 \%$ after $\mathrm{N}$ supply in forest soils.

Respect $\mathrm{N}_{\mathrm{MN}}$ dynamics presented by the Alfisol (Figure 1), control treatment and $\mathrm{M}_{1}$ generated a constant increase in $\mathrm{N}_{\mathrm{MN}}$ concentration during all incubation time. With exception of Control and $\mathrm{M}_{5}$ treatment, all treatments

Figure 1. Net concentration of total mineral $\mathrm{N}$ determined at each incubation time in an Alfisol.

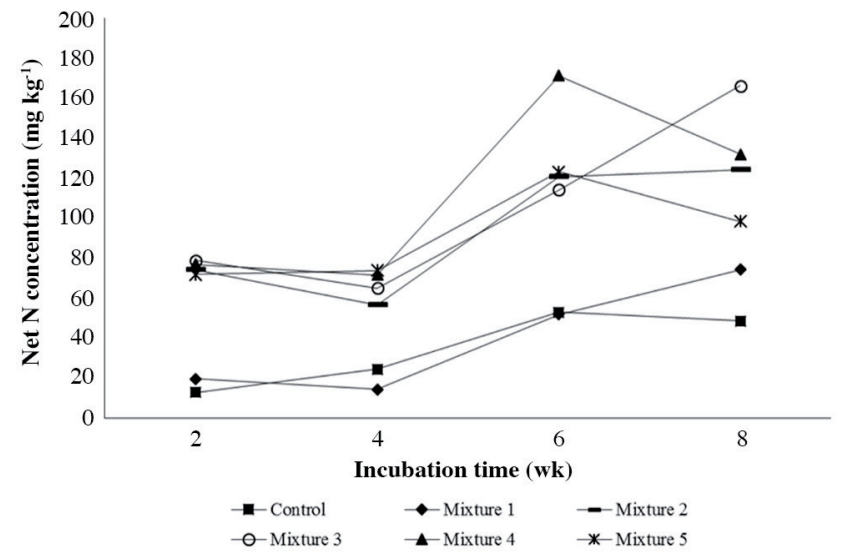

Mixture 1: $50 \%$ synthetic gypsum; 50\% coal ash. Mixture 2: $50 \%$ synthetic gypsum; 35\% coal ash; $15 \%$ urea. Mixture 3: $45 \%$ synthetic gypsum; $40 \%$ coal ash; $15 \%$ urea. Mixture 4: 65\% synthetic gypsum; $20 \%$ coal ash; $15 \%$ urea. Mixture 5: 55\% synthetic gypsum; 30\% coal ash; 15\% urea. 
had a slight decrease in $\mathrm{N}_{\mathrm{MN}}$ concentration during week 4. Later in week 6 , an increase in $\mathrm{N}_{\mathrm{MN}}$ was observed in all treatments, an increase that was maintained in treatments $\mathrm{M}_{1}, \mathrm{M}_{2}$ and $\mathrm{M}_{3}$ until that of week 8 evaluations. Treatments Control, $\mathbf{M}_{4}$ and $\mathbf{M}_{5}$ presented a decrease in $\mathrm{N}_{\mathrm{MN}}$ concentration in the last week of incubation generating differences between them $(p<0.05)$. The behavior of $\mathrm{N}_{\mathrm{MN}}$ concentration observed in Figure 1 is similar to that reported by Laos et al. (2000), Mohanty et al. (2013) and San Martín et al. (2016), who observed a steady increase in $\mathrm{N}_{\mathrm{MN}}$ concentration with mild lows between weeks. These results also were similar in all treatments to the results of Masunga et al. (2016) using different amendments used in agriculture from animal and green origin.

Due to the null contribution of $\mathrm{N}$ from the coal ash and FGD gypsum, the increase in $\mathrm{N}_{\mathrm{MN}}$ concentration is attributed to the mineralization of $\mathrm{OM}$ present in the soil and the mineralization of urea in treatments $\mathrm{M}_{2}, \mathrm{M}_{3}, \mathrm{M}_{4}$ and $\mathrm{M}_{5}$. A soil $\mathrm{N}$ concentration greater than $60 \mathrm{mg} \mathrm{kg}^{-1}$ is considered high. Based on this, Alfisol showed high concentrations of $\mathrm{N}$ available throughout the incubation time after applying treatments $\mathrm{M}_{2}, \mathrm{M}_{3}, \mathrm{M}_{4}$ and $\mathrm{M}_{5}$, whereas $\mathbf{M}_{1}$ only had a high concentration at week 8 . In this study, $\mathrm{N}_{\mathrm{MN}}$ concentrations were higher than those reported by San Martín et al. (2016), when applying pelleted waste from the paper industry with and without addition of Ulva lactuca L. in an Entisol.

\section{Potentially mineralizable $\mathbf{N}$}

The $\mathrm{N}_{0}$ and $\mathrm{k}$ determined for each treatment applied and their respective nonlinear equations, together with the mineral $\mathrm{N}$ concentration estimated by the first order nonlinear model are shown in Table 5 and Figure 2, respectively.

Figure 2. Accumulated mineral $\mathbf{N}$ concentration for each evaluation time estimated by first order nonlinear model for each treatment applied in an Alfisol.

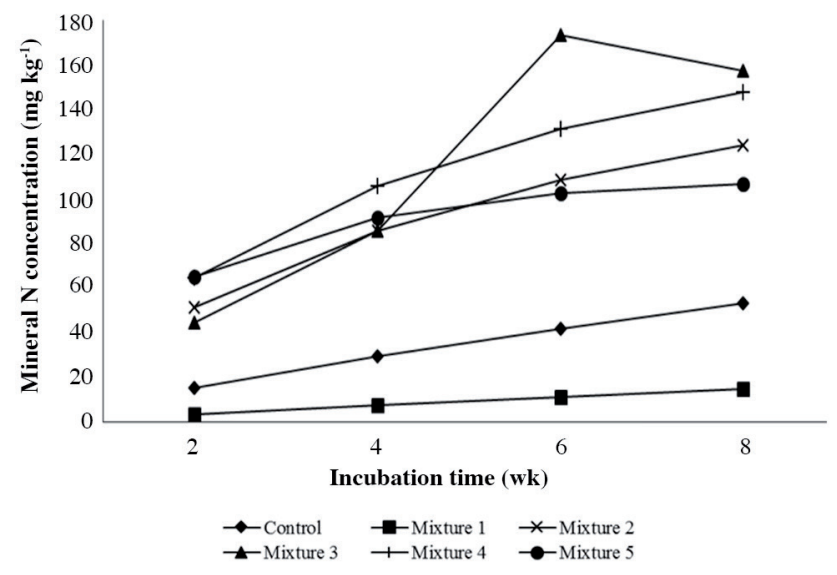

Mixture 1: $50 \%$ synthetic gypsum; $50 \%$ coal ash. Mixture 2: $50 \%$ synthetic gypsum; 35\% coal ash; $15 \%$ urea. Mixture 3: 45\% synthetic gypsum; $40 \%$ coal ash; $15 \%$ urea. Mixture 4: 65\% synthetic gypsum; $20 \%$ coal ash; $15 \%$ urea. Mixture 5: 55\% synthetic gypsum; 30\% coal ash; $15 \%$ urea.
Values of $\mathrm{N}_{0}$ refer to the amount of organic $\mathrm{N}$, which can be converted to inorganic forms soluble by microbial biomass activity (Ros et al., 2011). In this respect $\mathbf{M}_{1}$, which does not contain urea, presented the highest value of $\mathrm{N}_{0}$. However, it is observed that, when applying the $\mathrm{N}_{0}$ and $\mathrm{k}$ values determined in the nonlinear model, Control and $\mathrm{M}_{1}$ treatments show the lowest concentration of potentially mineralizable $\mathrm{N}$ (Figure 2). On the other hand, mixtures with urea in its formulation, $\mathrm{M}_{3}$ presented a $\mathrm{N}_{0}$ of $523 \mathrm{mg}$ $\mathrm{N} \mathrm{kg}^{-1}$ (Table 5). The values of the $\mathrm{N}_{0}$ in all treatments applied to Alfisol were higher than those reported by Hernández et al. (2002), Mohanty et al. (2013), and San Martín (2016). Because $\mathrm{N}_{0}$ values are calculated using net mineralization values, according to Guntiñas et al. (2012) it must be considered that $\mathrm{N}_{0}$ values will not depend only on the applied treatment, it also affects the type of use of the soil, moisture and temperature. Also must be considerate in future investigations that $\mathrm{N}_{0}$ values determined under laboratory conditions could differ from those determined in field conditions, because urea fertilization decreased the decomposition of plant residues and SOM in soils with growing plants (Li et al., 2017).

Regarding $\mathrm{k}$, values determined in control treatment, $M_{1}$ and $M_{3}$ were lower than those reported by Hernández et al. (2002), who determined $\mathrm{k}$ values of 0.6 and 1.14 when performing incubations of clay aggregate of 50 and $30 \mathrm{~g} \mathrm{~kg}^{-1}$ soil of urban sludge, respectively. Likewise, the values $\mathrm{k}$ for the Control and $\mathrm{M}_{1}$ treatment are lower than those determined by San Martín et al. (2016) in cellulose by-products without addition of $U$. lactuca. In mixtures with urea, $\mathrm{k}$ values of the treatments $\mathrm{M}_{2}, \mathrm{M}_{4}$ and $\mathrm{M}_{5}$ are within the range of 0.42 and 0.77 determined by San Martín et al. (2016), however the $\mathbf{M}_{3}$ treatment presented a value lower than this range. According to this, $\mathrm{k}$ values determined in Control treatment respond to its natural capacity of $\mathrm{N}$ release from its $\mathrm{OM}$ content, this way our results for Control treatment are higher than those reported by Dossa et al. (2009) in unamended sandy arid soils with low OM content. Nevertheless, with little exception of $\mathrm{M}_{1}$, all treatments shown $\mathrm{k}$ values higher than those reported by Mungai and Motavalli (2006) for green wastes. Moreover, in all our treatments without exclusion the results were

Table 5. Potentially mineralizable $\mathbf{N}\left(\mathbf{N}_{0}\right)$, rate of mineralization (k) and non-linear model fitted on an Alfisol.

\begin{tabular}{lccc}
\hline & \multicolumn{2}{c}{ Parameters } & \\
\cline { 2 - 3 } Treatments & $\mathrm{N}_{0}$ & $\mathrm{k}$ & Model \\
\hline Control & 149.9 & 0.05500 & $\mathrm{Nm}_{\mathrm{t}}=149.9\left[1-\mathrm{e}^{(-0.055 \mathrm{t})}\right]$ \\
Mixture 1 & 579.0 & 0.00331 & $\mathrm{Nm}_{\mathrm{t}}=579.0\left[1-\mathrm{e}^{(-0.00331 \mathrm{t})}\right]$ \\
Mixture 2 & 154.2 & 0.20350 & $\mathrm{Nm}_{\mathrm{t}}=154.2\left[1-\mathrm{e}^{(-0.2035 \mathrm{t})}\right]$ \\
Mixture 3 & 523.4 & 0.04470 & $\mathrm{Nm}_{\mathrm{t}}=523.4\left[1-\mathrm{e}^{(-0.0447 \mathrm{t})}\right]$ \\
Mixture 4 & 175.6 & 0.23080 & $\mathrm{Nm}_{\mathrm{t}}=175.6\left[1-\mathrm{e}^{(-0.2308 \mathrm{t})}\right]$ \\
Mixture 5 & 109.9 & 0.44990 & $\mathrm{Nm}_{\mathrm{t}}=109.9\left[1-\mathrm{e}^{(-0.4499 \mathrm{t})}\right]$ \\
\hline
\end{tabular}

Mixture 1: $50 \%$ synthetic gypsum; $50 \%$ coal ash. Mixture 2: $50 \%$ synthetic gypsum; 35\% coal ash; 15\% urea. Mixture 3: 45\% synthetic gypsum; 40\% coal ash; 15\% urea. Mixture 4: 65\% synthetic gypsum; 20\% coal ash; $15 \%$ urea. Mixture 5: 55\% synthetic gypsum; $30 \%$ coal ash; $15 \%$ urea.

$\mathrm{Nm}_{\mathrm{t}}$ : Accumulated mineral $\mathrm{N}$ at a specific time $\left(\mathrm{mg} \mathrm{kg}^{-1}\right)$. 
higher than those reported by Gil et al. (2011) with k values of 0.002 and 0.009 , when modelling $\mathrm{N}$ mineralization of bovine manure and sewage sludge compost in sandy clay loam soils.

Finally, a 32 wk projection of potentially mineralizable $\mathrm{N}$ is presented using the $\mathrm{N}_{0}$ and $\mathrm{k}$ values determined based on the results of the net mineralization test (Figure 3 ). The response observed in treatments $\mathrm{M}_{1}$ and $\mathrm{M}_{3}$ (Figure 3) is attributed to the high value of $\mathrm{N}_{0}$ and the low value of $\mathrm{k}$ determined by the Gauss-Newton method.

Figure 3. Estimated projection of accumulated mineral $\mathbf{N}$ concentration over $32 \mathrm{wk}$ using a first-order nonlinear model for each treatment applied in an Alfisol.

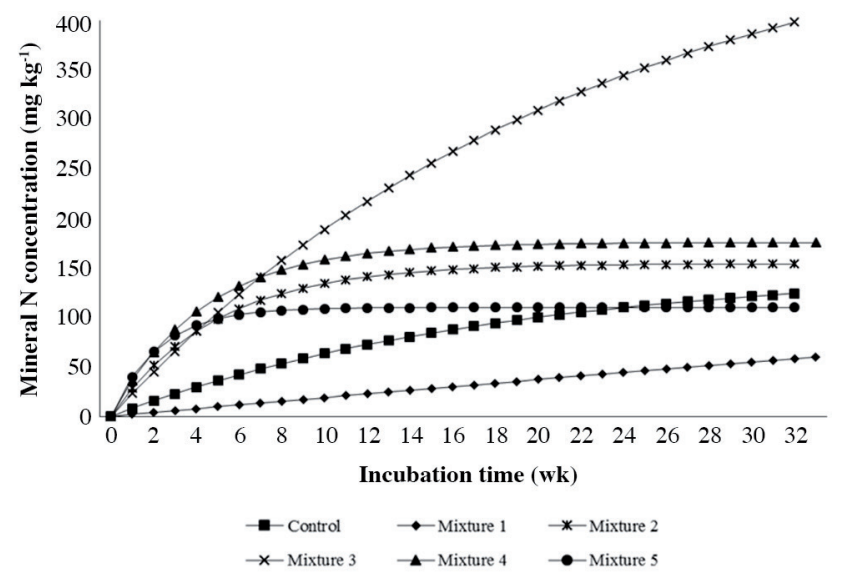

Mixture 1: 50\% synthetic gypsum; 50\% coal ash. Mixture 2: 50\% synthetic gypsum; 35\% coal ash; $15 \%$ urea. Mixture 3: $45 \%$ synthetic gypsum; $40 \%$ coal ash; $15 \%$ urea. Mixture 4: $65 \%$ synthetic gypsum; $20 \%$ coal ash; $15 \%$ urea. Mixture 5: 55\% synthetic gypsum; 30\% coal ash; $15 \%$ urea.

\section{CONCLUSIONS}

The application of gypsum FGD originated by flue gas desulfurization and coal ash without addition of urea generated the lowest concentrations of net mineral $\mathrm{N}$ available throughout the experiment. In this regard, increases in nitrogen mineralization appear to respond mainly to the urea content of the mixtures rather than to their proportion of by-products.

The values $\mathrm{N}_{0}$ and $\mathrm{k}$ would respond more to the fit of the mathematical model employed than to the actual biological process. Although the plotted curves agree with the theoretical response for the mineralization of $\mathrm{N}$, these could not constitute an accurate quantitative parameter. Since the methodology allows estimating the potential of mineralization of a soil in an approximate way, without considering the levels that could reach the soil system under certain conditions of temperature, humidity and $\mathrm{pH}$, in addition to the differences based on historical soil management.

\section{REFERENCES}

Chen, L., and Dick, W.A. 2011. Gypsum as an agricultural amendment: general use guidelines. Bulletin $\mathrm{N}^{\circ}$ 945. The Ohio State University Extension, Columbus, Ohio, USA.

Conant, R.T., Ogle, S.M., Paul, E.A., and Paustian, K. 2011. Measuring and monitoring soil organic carbon stocks in agricultural lands for climate mitigation. Frontiers in Ecology and the Environment 9(3):169-173.

DeSutter, T.M., and Cihacek, L.J. 2009. Potential agricultural uses of flue gas desulfurization gypsum in the Northern Great Plains. Agronomy Journal 101(4):817-825.

Dossa, E.L., Khouma, M., Diedhiou, I., Sene, M., Kinito, F., Badiane, A.N., et al. 2009. Carbon, nitrogen and phosphorus mineralization potential of semiarid Sahelian soils amended with native shrub residues. Geoderma 148:251-260.

Dungait, J.A.J., Hopkins, D.W., Gregory, A.S., and Whitmore, A.P. 2012. SOM turnover is governed by accessibility not recalcitrance. Global Change Biology 18:1781-1796.

Gil, M.V., Carballo, M.T., and Calvo, L.F. 2011. Modelling N mineralization from bovine manure and sewage sludge compost. Bioresource Technology 102: 863-871.

Gilmour, J.T., and Mauromoustakos, A. 2010. Nitrogen mineralization from soil organic matter: a sequential model. Soil Science Society of America Journal 75(1):317-323.

Guntiñas, M.E., Leirós, M.C. Trasar-Cepeda, C., and Gil-Sotres, F. 2012. Effects of moisture and temperature on net soil nitrogen mineralization: A laboratory study. European Journal of Soil Biology 48:73-80.

Hernández, T., Moral, R., Perez-Espinosa, A., Moreno-Caselles, J., Perez-Murcia, M.D., and García, C. 2002. Nitrogen mineralization potential in calcareous soils amended with sewage sludge. Bioresource Technology 83(3):213-219.

Hirzel, J., Undurraga, P., and Walter, I. 2010. Nitrogen mineralization and released nutrients in a volcanic soil amended with poultry litter. Chilean Journal of Agricultural Research 70:113-121.

Jastrow, J.D., Amonette, J.E., and Bailey, V.L. 2007. Mechanisms controlling soil carbon turnover and their potential application for enhancing carbon sequestration. Climate Change 80:5-23.

Keeney, D.R., and Nelson, D.W. 1982. Nitrogen-inorganic forms. p. 643-698. In Page, A.L. (ed.) Methods of soil analysis. Part 2. $2^{\text {nd }}$ ed. Agronomy 9. ASA and SSSA, Madison, Wisconsin, USA.

Kögel-Knabner, I., Guggenberger, G., Kleber, M., Kandeler, E., Kalbitz, K., Scheu, S., et al. 2008. Organo-mineral associations in temperate soils: integrating biology, mineralogy, and organic matter chemistry. Journal of Plant Nutrition and Soil Science 171(1):61-82.

Laos, F., Satti, P., Walter, I., Mazzarino, M.J., and Moyano, S. 2000. Nutrient availability of composted and non composted residues in a Patagonic Xeric Mollisol. Biology and Fertility of Soils 31(6):462-469.

Li, X.G., Jia, B., Lv, J., Ma, Q., Kuzyakov, Y., and Li, F. 2017. Nitrogen fertilization decreases the decomposition of soil organic matter and plant residues in planted soils. Soil Biology \& Biochemistry 112:47-55.

Masunga, R.H., Uzokwe, V.N., Mlay, P.D., Odeh, I., Singh, A., Buchan, D., et al. 2016. Nitrogen mineralization dynamics of different valuable organic amendments commonly used in agriculture. Applied Soil Ecology 101:185-193. 
Melotti, R., Santagata, E., Bassani, M., Salvo, M., and Rizzo, S. 2013. A preliminary investigation into the physical and chemical properties of biomass ashes used as aggregate fillers for bituminous mixtures. Waste Management 33:1906-1917.

Mohanty, S., Nayak, A.K., Kumar, A., Tripathi, R., Shahid, M., Bhattacharyya, P., et al. 2013. Carbon and nitrogen mineralization kinetics in soil of rice-rice system under long term application of chemical fertilizers and farmyard manure. European Journal of Soil Biology 58:113-121.

Mungai, N.W., and Motavalli, P.P. 2006. Litter quality effects on soil carbon and nitrogen dynamics in temperate alley cropping systems. Applied Soil Ecology 31:32-42.

Nave, L.E., Vance, E.D., Swanston, C.W., and Curtis, P.S. 2009. Impacts of elevated $\mathrm{N}$ inputs on north temperate forest soil $\mathrm{C}$ storage, C/N, and net N-mineralization. Geoderma 153:231-240.

Niu, Y., Houzhang, T., and Hui, S. 2016. Ash-related issues during biomass combustion: Alkali-induced slagging, silicate meltinduced slagging (ash fusion), agglomeration, corrosion, ash utilization, and related countermeasures. Progress in Energy and Combustion Science 52:1-61.

Rahman, M.H., Islam, M.R., Jahiruddin, M., Puteh, A.B., and Mondal, M.M.A. 2013. Influence of organic matter on nitrogen mineralization pattern in soils under different moisture regimes. International Journal of Agricultural Biology 15(1):55-61.

Ram, L.C., and Masto, R.E. 2014. Fly ash for soil amelioration: A review on the influence of ash blending with inorganic and organic amendments. Earth-Science Reviews 128:52-74.

Ram, L.C., Masto, R.E., Singh, S., Tripathi, R.C., Jha, S.K., Srivastava, et al. 2011. An appraisal of coal fly ash soil amendment technology (FASAT) of Central Institute of Mining and Fuel Research (CIMFR). World Academy of Science, Engineering and Technology 76:703-714.

Ros, G.H., Temminghoff, E.J.M., and Hoffland, E. 2011. Nitrogen mineralization: A review and meta-analysis of the predictive value of soil tests. European Journal of Soil Science 62:162-173.

Sadzawka, A.R., Carrasco, M.A., Grez, R., Mora, M.L., Flores, H., y Neaman, A. 2006. Métodos de análisis recomendados para los suelos de Chile. Revisión 2006. Serie Actas INIA $\mathrm{N}^{\mathrm{o}}$ 34. Instituto de Investigaciones Agropecuarias INIA, Santiago, Chile.
San Martín, V. 2016. Evaluación agronómica de residuos peletizados de la industria del papel en asociación con alga marina Ulva lactuca L.: posible utilización como biofertilizantes y efectos en la mineralización del nitrógeno. Tesis Magíster en Ciencias Agronómicas con mención en Ciencias del Suelo y Recursos Naturales. Universidad de Concepción, Facultad de Agronomía, Chillán, Chile.

San Martín, V., Undurraga, P., Quezada, C., Célis, J.E., and Sandoval, M. 2016. Effect of pellets made of waste materials from the paper industry enhanced with seaweed (Ulva lactuca $\mathrm{L}$.) on $\mathrm{N}$ mineralization and lettuce production. Chilean Journal of Agricultural Research 76:363-370.

Sandoval, M., Celis, J., Stolpe, N., and Capulín, J. 2010. Effect of sewage sludge and salmon wastes amendments on the structure of an Entisol and Alfisol in Chile. Agrociencia 44(5):503-515.

Sandoval, M., Dörner, J., Seguel, O., Cuevas, J., y Rivera, D. 2012. Métodos de análisis físicos de suelo. Publicaciones del Departamento de Suelos y Recursos Naturales N5. Universidad de Concepción, Chillán, Chile.

Seshadri, B., Bolan, N.S., and Kunhikrishnan, A. 2013. Effect of clean coal combustion products in reducing soluble phosphorus in soil. I. Adsorption study. Water Air Soil Pollution 224(4): 1524.

Shaheen, S.M., Hooda, P.S., and Tsadillas, Ch.D. 2014. Opportunities and challenges in the use of coal fly ash for soil improvements - A review. Journal of Environmental Management 145:249-267.

Stolpe, N. 2006. Descripciones de los principales suelos de la VIII Región de Chile. Publicaciones del Departamento de Suelos y Recursos Naturales $N^{\circ} 1$. Universidad de Concepción, Chillán, Chile.

Tyagi, V.K., and Lo, S.L. 2013. Sludge: A waste or renewable source for energy and resources recovery? Renewable and Sustainable Energy Reviews 25:708-728.

Vassilev, S.V., Baxter, D., Andersen, L.K., and Vassileva, C.G. 2013. An overview of the composition and application of biomass ash Part 1. Phase-mineral and chemical composition and classification. Fuel 105:40-76. 